\title{
Sustainable Supplier Selection in Agri-Food Supply Chain Management
}

\author{
Nesrin Ada \\ Department of Business Administration, \\ Ege University, Bornova, Izmir, Turkey. \\ E-mail: nesrinada@yahoo.com.tr
}

(Received on December 12, 2021; Accepted on January 3, 2022)

\begin{abstract}
In recent times, sustainability of supply chains becomes the most interested subject by customers, firms, government bodies, academia, and suppliers as the environmental resources reveal as the most valuable and limited asset for human beings. One of the most important elements determining the performance of sustainable agri-food supply chain business is supplier's commitment. A mainly inspiring feature in this domain is the wide range of factors influencing supplier selection decision-making process in Triple Bottom Line context must be analyzed. However, it is not easy to completely integrate and measure majority of these factors in a simple optimization model. Therefore, this paper starts with a comprehensive review of literature about supplier selection for sustainable supply chains (SSCs) development. Afterwards, a new two-steps hybrid solution method is suggested. In initial step, a set of criteria for supplier selection process is analyzed built on Fuzzy Analytic Network Process (FANP). The result of the first step is fed in to the second step of the analysis to design a model with multiple objectives for selection process of supplier using fuzzy VIKOR. All three dimensions of sustainability; specifically, factors such as weather, water and soil footprint, energy and material consumption, employment, social services and finally financial performance of supply chain are considered concurrently. The suggested approach generates a comprehensive model to help supply chain managers in supplier selection process. Numerical analysis is completed via exploiting data from a Turkish agri-food company case for validating effectiveness, also and success of the proposed solution. Final analytical results of the analysis provide valuable business policy oriented, operational and practical insights on the influence of economic, environmental, and social sustainability for enhanced supplier relationship management module in sustainable supply chain structure. Moreover, by tracking environmental impact indicators such as, emission and pollution rates, footprint rates, against social and cost indicators it would be possible to perform tradeoff analysis for giving more sustainable decisions on new supply chain investments.
\end{abstract}

Keywords- Sustainability, Agri-food supply chain, Supplier selection decision-making, Multi-objective model, Fuzzy analytic network process.

\section{Introduction}

Currently it is possible to observe the strong pressure from all stakeholders such as customers, government, policy makers, and non-government organizations and especially suppliers of agrifood supply chains to deal with sustainability as a result of increasing financial, environmental, and social distresses and increased strategic importance of food production and consumption (Barbosa, 2021). It is obvious that trend in agri-food SSCs will continue over the following years. Reaching sustainability will result in substantial economic development, healthy environment, and social welfare. Therefore, an SSC can be defined as a system in which organizational structure, managerial policies and all managerial functions, activities, operations, logistics in supply chain management (SCM) are performed through circularity and sustainable development (Ciccullo et al., 2021).

It is an important trend to take into consideration sustainability in agri-food supply chain. Meanwhile, several international organizations and programs place the issue into their agenda due to resulting obvious economic, social, and environmental impacts. For instance, food consumption and agricultural activities are claimed as important elements of environmental pressures such as 
climate change, toxic emissions, and water usage (UNEP, 2010). At the same time, other factors, economic and social, are extremely important. Furthermore, ensuring sustainability in the agri-food supply chain also increases the resilience of the supply chains in the face of sudden disruptions (Gkountani et al., 2021).

It can be observed that, main subject of the recent studies in this filed is to develop SSC design for the whole supply chain system. Significant number of studies have focused on investigating productivity and financial performance measures, as well as the effect of sustainability dimensions and managerial policies on agri-food supply chain (Reklitis et al., 2021). The initial step of supply chain, which is the most critical part of sustainable supply chain management (SSCM) modeling, is supplier relations and supplier selection decision considered in logistics management. Though, many of these models have considered optimization of cost-based financial metrics, generation of revenue or reduction of costs. Environmental and social metrics have a minor role if any, compared to financial and operational metrics (Xie, 2015).

From another point of view, supplier selection is also very important to ensure sustainability in supply chains (Beiki et al., 2021). Sustainability and supplier selection are directly related to each other (Zhang et al., 2021). In order to ensure sustainability in supply chains, supplier selections should also be evaluated within the framework of the dimensions of sustainability (Verdecho et al., 2021).

Efforts spend for supplier selection within agri-food supply chains became effective to reduce the gaps in prescribed modeling studies by inspecting supplier side features and such modeling efforts become more difficult when sustainability is integrated into the cost-oriented supplier selection approaches (Badraoui et al., 2021). Therefore, it is essential to focus on sustainability dimensions for agri-food supply chains.

In this context, broad range of effective sustainability factors need to be considered with a fully integrated multi-objective model for supplier selection process. Interactions between economic, environmental, and social criteria must be defined with interdisciplinary technical approach for the realization of model development. Identifying requirements of sustainability for agri-food supply chain and integrating them into the supplier selection process with a holistic approach is the main goal of the study. Indeed, some papers use optimization approach to design agri-food supply chain by considering all three dimensions of sustainability, but in-depth emphasis must be given to supplier selection part of the problem.

On the other hand, managers of supply chain systems prefer to consider economic, social, and environmental factors together within supplier relationship, network design, logistics and customer relationship modules of the whole supply chain. Such an approach transforms the solution method of decision-making problem into a hybrid model. Nowadays, an increasing insistence on supply chain stakeholders to decrease their pollution, environmental threats, and carbon emission levels is observed (Shaw et al., 2012).

Decision support systems and techniques equipped with sustainability attributes can help managers to give more operational and creative decision-making opportunities in designing agri-food supplychains (Santoso et al., 2021). The proposed two-stage solution methodology of this study contributes to sustainable agri-food supply chain design studies in terms of developing sustainable supplier selection decision model. 
In the first step, several sustainability criteria in agri-food supply chain, including sustainability factors are weighted by pairwise comparisons of the experts using Fuzzy ANP for supplier selection (Step I). The result of the first step with the weights of the criteria are utilized in step 2 to develop a hybrid model for supplier selection process. Fuzzy VIKOR model with multiple objective function were formulated based on a decision support system to be used in selection of suppliers were developed (Step II). The research questions of this study were developed as:

RQ1: What are the criteria to be used for sustainable supplier selection process?

RQ2: What solutions methods may be used to find the appropriate results?

Additionally, this study examines how the proposed model is applicable by using a demonstrative case study in Turkish agri-food industry to display the success and effectiveness of our approach. In the remaining part of the paper following issues have been covered. In part 2, review of the literature on supplier selection problem, research instruments with the techniques for the development of sustainable supply chains are given. Part 3 presents the proposed framework and methodology for sustainable supplier selection within agri-food supply chain. Part 4 includes case study for supplier selection in agri-food supply chain in order to demonstrate implementation of anticipated approach. Finally, in Part 5, article succeeds with conclusion and discussion about implications and a note about future studies.

\section{Literature Review}

Research on supply chain in the context of triple bottom line is multidisciplinary in nature and accordingly can be found in several related fields. Supplier selection process for food supply chains (FCS) has received limited attention due to the complexities of food industry. There are limited number of studies published. Yazdani et al. (2021a) made a holistic decision analysis for supplier selection process in FCS with a multi-criteria approach. Puška et al. (2021) also aimed to use interval fuzzy logic for sustainable supplier selection grounded on agricultural production. Tavana et al. (2017) provided an integrated multi-criteria decision-making approach to for sustainable supplier selection decision-making process. Moreover, Banaeian et al. (2018) integrated GRA, VIKOR, and TOPSIS methods in supplier selection process within a fuzzy environment and evaluate green supplier alternatives in the agri-food industry. Moreover, Zhang et al. (2021) used Rough DEMATEL and Fuzzy VIKOR for supplier selection in supply chains.

In addition, Liu et al. (2019) integrated fuzzy set theory, AHP, and TOPSIS to construct a fuzzy decision method to measure the performance sustainable suppliers. Also, Yazdani et al. (2021b) proposed a long-term supplier assessment framework based on several criteria and an IVFN (interval-valued fuzzy neutrosophic) model. Shi et al. (2018) studied a unique integrated strategy for assessing green suppliers based on IVIULSs, GRA, and TOPSIS. Furthermore, Orji and Ojadi (2021) investigated impacts of pandemics on supplier selection process. Moreover, Lu et al. (2021) focused on green supplier selection and used COPRAS method. Similarly, Mabrouk (2021) addressing green supplier selection to reached sustainable supplier selection process by using Fuzzy Delphi method.

Agri-product supply chains should prioritize digital marketing via an efficient e-advertising channel to satisfy the needs and wants of future generations (Alkahtani et al., 2021). In this context, Hong et al. (2018) provided a blockchain-based agricultural product tracking system based on the Internet of Things thus, it can follow the entire process from the minute an agri-product is born, considerably increasing customer trust in the food, and improving brand protection. Furthermore, Costa et al. 
(2013) point out how RFID technology is increasingly being used to track agri-food items at various phases of the supply chain, from manufacture through transport to final merchandising. Sharma et al. (2021) focused on intelligent agri-food supply chains and find solutions for waste with IoT technologies. Moreover, Rana et al. (2021) completed systematic literature review about blockchain technology in agri-food supply chains and they tried to find an answer that how blockchain technologies can be adopted in agri-food supply chains. Similarly, Saurabh and Dey (2021) focused on adoption of blockchain technology in agri-food supply chains.

Moreover, Ahumada and Villalobos (2009) assessed the planning of various components of agrifood supply chains in their study. Meena et al. (2019) highlighted strengths, weaknesses, opportunities, and threats of agri-food supply chain using AHP based SWOT analysis method. Moreover, Kaur and Singh (2021) proposed a multi-stage hybrid model for supplier selection by considering disruptive technologies. Furthermore, Mishra et al. (2021) focused on impacts of disruptions and resilience on agri-food supply chains. From another point of view, Mahmoudi et al. (2021) addressing green supplier selection by considering the ordinal priority approach and grey systems.

The cold supply chain is considered as a system in which all the operations involved are temperature-controlled in every stage of product delivery (Gogou et al., 2015). Therefore, sustainable supplier selection within cold supply chain is also vital topic for different disciplines. For instance, Yan et al. (2020), examined the factors that influence a supplier's decision to use normal temperature or cold chain transportation in fresh Agri-products, as well as the impact of different modes of transportation on the decisions of retailers in terms of loss of value for fresh Agri-products. Khan and Ali (2021) identified the enablers to create a viable and long-term frozen food provider and used interpretative structural modeling (ISM) approach with the MICMAC analysis for analyzing enablers to select a long-term cold supplier in Pakistan. Yu et al. (2020) studied the price and decision of cold-chain services and evaluated the effects of (horizontal/vertical) integration on the decisions and profits made.

Sustainable fresh agricultural product supplier selection has become a critical element for green agricultural product supply chains (Du et al., 2020). Considering this, De and Singh (2021) examined how the channel leadership strategies contribute to the development of a post-COVID19 resilient agri-supply chain. Yu and Xiao (2017) have conducted research aiming to evaluate the effects of channel leadership on price and service level decisions and profits. Du et al. (2020) offered a new index for evaluating the process of selecting sustainable providers of fresh agricultural goods, based on TBL dimensions, which are social, environmental, and economic considerations.

To sum up, sustainability is the most important factor to consider during supplier selection. By considering the previous studies, sustainable supplier selection has been discussed for many different supply chains such as cold supply chain, fresh food supply chain etc. As mentioned before, the importance and manageability of agri-food supply chains come to the fore due to the complex structure of agri-food supply chains (Kaur and Singh, 2021). Therefore, the most important element in agri-food supply chains is sustainability (Badraoui et al., 2021).

Based on a literature review, the criteria set was determined. The criteria used in this study for supplier selection process were adapted from Sagnak (2019). Table 1 shows the criteria set. 
Table 1. Criteria set.

\begin{tabular}{|c|c|c|c|c|c|}
\hline C1 - Economic & $\begin{array}{l}\text { C2 - Quality } \\
\text { Issues }\end{array}$ & $\begin{array}{l}\text { C3 - Sustainable } \\
\text { Management } \\
\text { Systems }\end{array}$ & C4 - Performance & $\begin{array}{c}\text { C5 - } \\
\text { Trustworthiness }\end{array}$ & $\begin{array}{c}\text { C6 - Technological } \\
\text { Ability }\end{array}$ \\
\hline $\begin{array}{c}\mathrm{C} 1_{1}-\text { Cost of } \\
\text { Materials }\end{array}$ & $\mathrm{C} 2_{1}$ - Assurance & $\begin{array}{c}\mathrm{C} 3_{1}-\text { Sustainable } \\
\text { Design }\end{array}$ & $\begin{array}{c}\mathrm{C} 4_{1}-\text { Delivery on } \\
\text { Time }\end{array}$ & $\mathrm{C} 5_{1}$ - Credibility & $\begin{array}{c}\mathrm{C} 6_{1}-\text { Information } \\
\text { System }\end{array}$ \\
\hline $\begin{array}{l}\mathrm{Cl}_{2}-\text { Cost of } \\
\text { Transportation }\end{array}$ & $\begin{array}{c}\mathrm{C} 2_{2}- \\
\text { Certifications }\end{array}$ & $\mathrm{C} 3_{2}-$ Energy-Saving & $\begin{array}{l}\mathrm{C} 4_{2}-\text { Ability of } \\
\text { Communication }\end{array}$ & $\begin{array}{c}\mathrm{C} 5_{2}-\text { Corporate } \\
\text { Social } \\
\text { Responsibility }\end{array}$ & $\begin{array}{c}\mathrm{C6}_{2}-\text { Eco-friendly } \\
\text { Technology }\end{array}$ \\
\hline $\mathrm{C}_{3}$ - Discounts & $\mathrm{C} 2_{3}-$ Reliability & $\begin{array}{c}\mathrm{C} 3_{3}-\text { Reduction of } \\
\text { Pollution }\end{array}$ & $\mathrm{C}_{3}$ - Capacity & $\mathrm{C} 5_{3}-$ Reputation & $\begin{array}{c}\mathrm{C} 6_{3}-\text { Level of } \\
\text { Technology }\end{array}$ \\
\hline $\mathrm{Cl}_{4}$ - Duty & $\begin{array}{c}\mathrm{C} 2_{4}- \\
\text { Innovativeness }\end{array}$ & $\begin{array}{l}\mathrm{C} 3_{4} \text { - Sustainable } \\
\text { Manufacturing }\end{array}$ & $\mathrm{C}_{4}$ - Distance & $\begin{array}{c}\mathrm{C5}_{4}- \\
\text { Compatibility to } \\
\text { Law }\end{array}$ & $\begin{array}{c}\mathrm{C}_{4}-\text { Sustainable } \\
\text { Production } \\
\text { Technologies }\end{array}$ \\
\hline $\begin{array}{l}\mathrm{C}_{1}-\text { Cost of } \\
\text { Ordering }\end{array}$ & $\mathrm{C} 2_{5}-\mathrm{R} \& \mathrm{D}$ & $\begin{array}{c}\mathrm{C} 3_{5}-\text { Reverse } \\
\text { Logistics }\end{array}$ & $\mathrm{C}_{4}$ - Fulfillment Rate & & \\
\hline \multirow[t]{16}{*}{$\begin{array}{c}\mathrm{Cl}_{6}-\text { Price } \\
\text { Performance } \\
\text { Ratio } \\
\end{array}$} & $\begin{array}{c}\mathrm{C} 26_{6}^{-} \\
\text {Improvement }\end{array}$ & $\begin{array}{c}\mathrm{C} 3_{6}-\text { Sustainable } \\
\text { Image }\end{array}$ & $\mathrm{C}_{6}$ - Lead Time & & \\
\hline & $\mathrm{C} 2_{7}-\mathrm{TQM}$ & $\begin{array}{l}\mathrm{C} 3_{7}-\text { Sustainable } \\
\text { Purchasing }\end{array}$ & $\mathrm{C} 4_{7}-$ Reactivity & & \\
\hline & & $\begin{array}{l}\mathrm{C} 3_{8}-\text { Sustainable } \\
\text { Logistics }\end{array}$ & $\mathrm{C} 4_{8}$ - Warranty & & \\
\hline & & $\begin{array}{l}\mathrm{C} 3_{9}-\text { Sustainable } \\
\text { Packaging }\end{array}$ & $\begin{array}{l}\mathrm{C} 4_{9}-\text { Consumer } \\
\text { Satisfaction }\end{array}$ & & \\
\hline & & $\mathrm{C} 3_{10}-$ Waste Control & $\begin{array}{c}\mathrm{C} 4_{10}-\text { After Sale } \\
\text { Management }\end{array}$ & & \\
\hline & & $\begin{array}{l}\mathrm{C} 3_{11} \text { - Using Eco- } \\
\text { friendly Materials }\end{array}$ & $\mathrm{C}_{11}-$ Resilience & & \\
\hline & & $\begin{array}{l}\mathrm{C} 3_{12} \text { - Dedication to } \\
\text { Sustainable Practices }\end{array}$ & $\mathrm{C} 4_{12}$ - Productiveness & & \\
\hline & & & $\begin{array}{c}\mathrm{C} 4_{13}-\text { Technical } \\
\text { Caliber }\end{array}$ & & \\
\hline & & & $\mathrm{C} 4_{14}-$ Shelf Conditions & & \\
\hline & & & $\begin{array}{c}\mathrm{C} 4_{15}-\text { Rate of } \\
\text { Rejections }\end{array}$ & & \\
\hline & & & $\begin{array}{c}\mathrm{C} 4_{16}-\text { Frequency of } \\
\text { Orders }\end{array}$ & & \\
\hline & & & $\begin{array}{l}\mathrm{C} 4_{17}-\text { Stock } \\
\text { Management }\end{array}$ & & \\
\hline & & & $\mathrm{C}_{18}-$ Risk & & \\
\hline & & & $\mathrm{C} 4_{19}-$ Security & & \\
\hline & & & $\mathrm{C} 4_{20}$ - Strategic Fitness & & \\
\hline & & & $\mathrm{C} 4_{21}$ - Support & & \\
\hline
\end{tabular}

The criteria set was validated by two academics, and three industrial experts. The experts found criteria set applicable for agri-product supplier selection process. The weights of the criteria were found using Fuzzy ANP. Then, the rankings of the seven suppliers were calculated using Fuzzy VIKOR. The reason to select fuzzy ANP is its ability to prioritize the respective weights of criteria. The fuzzy VIKOR is used because its ability to rank various alternatives is very high.

\section{Proposed Framework}

The theoretical background of this paper draws on the research areas of sustainable supply chain management and sustainable supplier selection process. Figure 1 shows the main flow and structure of the paper including the proposed framework as a flowchart, to present a clear overview of the research stages. 


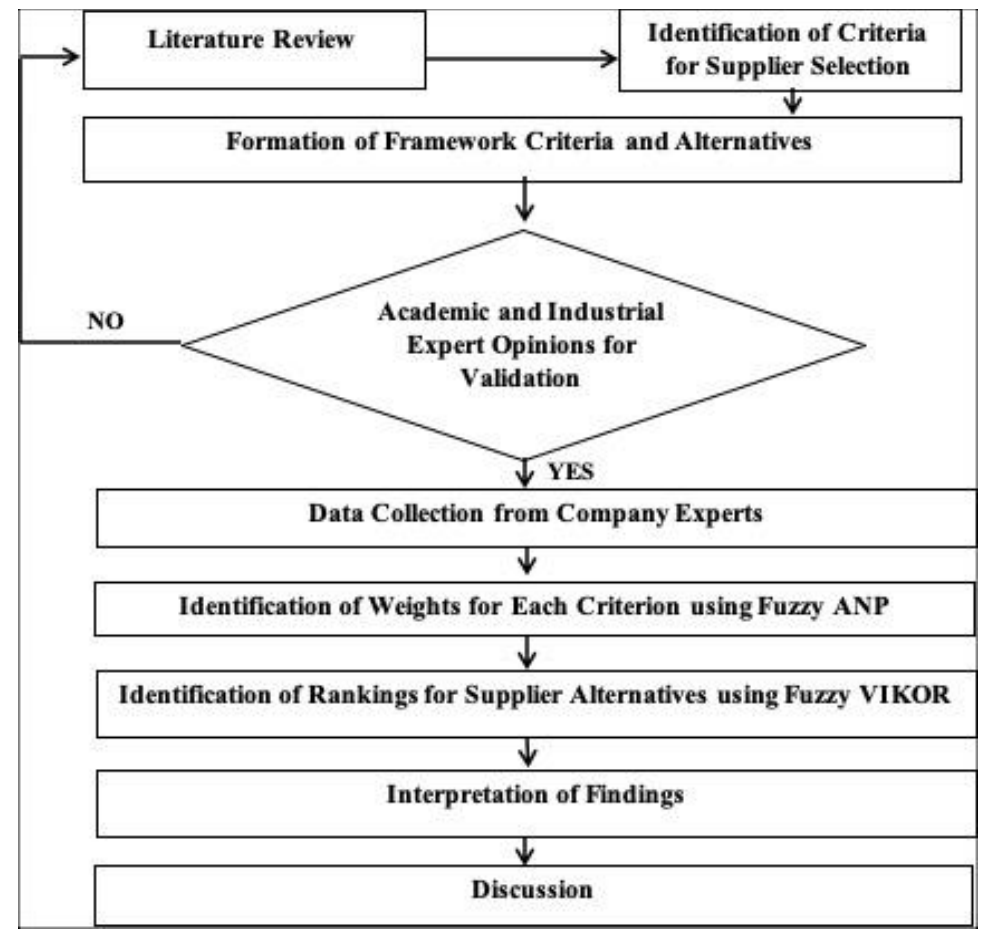

Figure 1. Methodology.

\section{Case Study}

Case studies are useful to examine multifactor problem situations in the regular setting to improve understanding of the model and its applicability. Using case studies in a research means that the complete model structure can be addressed. Furthermore, difficult and wide-range of problem variables, convenient research questions can be under review by collecting qualitative or quantitative data about the case, and the researchers can do in-depth analysis the problem situation. The contribution of the case study is illustrated in the example given in this paper.

The proposed model of this study has been put into practice for seven agri-product supplier companies located in Izmir, Turkey. The most important data requirements of the model have been collected depending on expert opinions and their experience. For the first step of the model, data collection process based on all the pairwise comparisons of the criteria by experienced managers of supply chains. The criteria set includes 6 main criteria, and a total of 54 sub-criteria. The weights of the main criteria, which was found using Fuzzy ANP, can be seen in Table 2.

Table 2. Weights of main criteria.

\begin{tabular}{|c|c|}
\hline Main Criteria & Weights \\
\hline Economic & 0.4407 \\
\hline Quality Issues & 0.2446 \\
\hline Sustainable Management Systems & 0.1699 \\
\hline Performance & 0.0545 \\
\hline Trustworthiness & 0.0564 \\
\hline Technological Ability & 0.0340 \\
\hline
\end{tabular}


Analysis of the main criteria weights indicates that financial and economic criteria is the most important for supplier selection. On the other hand, Sustainable Management Systems with 17\% percent weight has a reasonable degree of importance, and this is promising for an emerging economy and for the future of sustainability in Turkey. The weights of sub-criteria within economic cluster can be seen in Table 3 .

Table 3. Weights of sub-criteria within economic cluster.

\begin{tabular}{|c|c|}
\hline Sub-Criteria & Weights \\
\hline $\mathrm{C} 1_{1}-$ Cost of Materials & 0.3853 \\
\hline $\mathrm{C} 1_{2}-$ Cost of Transportation & 0.2495 \\
\hline $\mathrm{C} 1_{3}$ - Discounts & 0.1120 \\
\hline $\mathrm{C} 1_{4}$ - Duty & 0.0753 \\
\hline $\mathrm{C} 1_{5}-$ Cost of Ordering & 0.0837 \\
\hline $\mathrm{C} 1_{6}-$ Price Performance Ratio & 0.0941 \\
\hline
\end{tabular}

Within the framework of economic criteria, cost of materials and cost of transportation together cover $63 \%$ of the weight and it is essential to select supplier with implementation of economic criteria. In this framework, Turkish supply chain companies are under the pressure of material, transportation and other cost factors, which is in coincidence with economic indicators. Moreover, the recent developments in Turkey on sustainability, establishment of "Ministry of Environment, Urbanization and Climate Change" (https://csb.gov.tr/en), Economic Reform Program is a policy framework for business companies to the direction of circular economy and sustainability.

The weights of sub-criteria within quality issues cluster can be seen in Table 4 . Total weight of quality sub criteria is about $25 \%$ and makes a substantial contribution is supplier selection decision. Assurance, innovativeness and reliability are the most important criteria with the weight of $60 \%$ to select the supplier. Criteria can be used in systematic reviews of supplier selection to detect deficiencies and gaps in knowledge of measurement properties. Particularly on quality criteria for good measurement of supplier performance, the future task can be to improve and complete the criteria.

Table 4. Weights of sub-criteria within quality issues cluster.

\begin{tabular}{|c|c|}
\hline Sub-Criteria & Weights \\
\hline $\mathrm{C} 2_{1}-$ Assurance & 0.2255 \\
\hline $\mathrm{C} 2_{2}-$ Certifications & 0.1261 \\
\hline $\mathrm{C} 2_{3}-$ Reliability & 0.1595 \\
\hline $\mathrm{C} 2_{4}-$ Innovativeness & 0.2089 \\
\hline $\mathrm{C} 2_{5}-\mathrm{R} \& \mathrm{D}$ & 0.0874 \\
\hline $\mathrm{C} 2_{6}-$ Improvement & 0.1164 \\
\hline $\mathrm{C} 2_{7}-\mathrm{TQM}$ & 0.0763 \\
\hline
\end{tabular}

The weights of sub-criteria within sustainable management systems cluster can be seen in Table 5 . Presence of market economy needs economic stability, competitive service and product markets through cultivating sustainability and environment, establishing a well-functioning legal system, achieving financial stability for financial markets, high employment rates. Availability of sustainable management systems is a critical issue for the success of agri-food supply chains in a competitive market economy and especially important for the selection of suppliers. In our proposed model, criteria set of sustainable management systems and twelve sub criteria enforce the 
supplier selection decision for sustainability. The total weight of the cluster is $17 \%$ and the most important sub criteria are sustainable manufacturing sustainable design, reverse logistics and energy saving. The weight of available sustainable manufacturing facilities by the supplier is encouraging and contributes sustainability goals of the food supply chain. Furthermore, criteria such as energy saving, and reduction of pollution are considered as sustainability features of the supplier by the model and final supplier selection decision will serve triple bottom line targets.

Table 5. Weights of sub-criteria within sustainable management systems cluster.

\begin{tabular}{|c|c|}
\hline Sub-Criteria & Weights \\
\hline $\mathrm{C} 3_{1}-$ Sustainable Design & 0.1180 \\
\hline $\mathrm{C} 3_{2}-$ Energy-Saving & 0.1688 \\
\hline $\mathrm{C} 3_{3}-$ Reduction of Pollution & 0.1242 \\
\hline $\mathrm{C} 3_{4}-$ Sustainable Manufacturing & 0.1708 \\
\hline $\mathrm{C} 3_{5}-$ Reverse Logistics & 0.1356 \\
\hline $\mathrm{C} 3_{6}-$ Sustainable Image & 0.0289 \\
\hline $\mathrm{C} 3_{7}-$ Sustainable Purchasing & 0.0419 \\
\hline $\mathrm{C} 3_{8}-$ Sustainable Logistics & 0.0611 \\
\hline $\mathrm{C} 3_{9}-$ Sustainable Packaging & 0.0437 \\
\hline $\mathrm{C} 3_{10}-$ Waste Control & 0.0465 \\
\hline $\mathrm{C} 3_{11}-$ Using Eco-friendly Materials & 0.0347 \\
\hline $\mathrm{C} 3_{12}-$ Dedication to Sustainable Practices & 0.0258 \\
\hline
\end{tabular}

The weights of sub-criteria within performance cluster can be seen in Table 6. Performance cluster criteria are necessary to evaluate the suppliers from managerial and operational point of view and sub criteria of this cluster directly or indirectly are effective on economic and environmental aspects of the selection process. The total weight of the performance criteria is about $6 \%$ which is relatively low when we compare with the weights of economic and environmental criteria but indirect must be considered as an additional contribution.

Table 6. Weights of sub-criteria within performance cluster.

\begin{tabular}{|c|c|}
\hline Sub-Criteria & Weights \\
\hline $\mathrm{C} 4_{1}$ - Delivery on Time & 0.0664 \\
\hline $\mathrm{C}_{4}-$ Ability of Communication & 0.0743 \\
\hline $\mathrm{C}_{3}$ - Capacity & 0.0721 \\
\hline $\mathrm{C} 4_{4}$ - Distance & 0.0584 \\
\hline $\mathrm{C} 4_{5}$ - Fulfillment Rate & 0.0652 \\
\hline $\mathrm{C} 4_{6}$ - Lead Time & 0.0496 \\
\hline $\mathrm{C} 4_{7}$ - Reactivity & 0.0483 \\
\hline $\mathrm{C} 4_{8}$ - Warranty & 0.0351 \\
\hline $\mathrm{C}_{4}$ - Consumer Satisfaction & 0.1582 \\
\hline $\mathrm{C} 4_{10}$ - After Sale Management & 0.0392 \\
\hline $\mathrm{C} 4_{11}-$ Resilience & 0.0371 \\
\hline $\mathrm{C} 4_{12}$ - Productiveness & 0.0745 \\
\hline $\mathrm{C}_{13}-$ Technical Caliber & 0.0259 \\
\hline $\mathrm{C} 4_{14}$ - Shelf Conditions & 0.0256 \\
\hline $\mathrm{C} 4_{15}-$ Rate of Rejections & 0.0250 \\
\hline $\mathrm{C} 4_{16}-$ Frequency of Orders & 0.0231 \\
\hline $\mathrm{C} 4_{17}$ - Stock Management & 0.0325 \\
\hline $\mathrm{C} 4_{18}-$ Risk & 0.0262 \\
\hline $\mathrm{C} 4_{19}$ - Security & 0.0222 \\
\hline $\mathrm{C}_{20}$ - Strategic Fitness & 0.0207 \\
\hline $\mathrm{C}_{21}-$ Support & 0.0203 \\
\hline
\end{tabular}


The most important sub criteria are consumer satisfaction, capacity, communication ability and delivery on time are effective on the final supplier decision. Managerial performance of the supplier is a powerful feature and will contribute to the managerial and operational success of agri-food supply chain. It brings a comprehensive set of criteria to help decision maker to select the supplier with satisfying infrastructure and managerial capabilities. It gives the necessary flexibility for supply chain management to add customized features that are based on specific requirements of their sustainability goals.

The weights of sub-criteria within trustworthiness cluster can be seen in Table 7. Trustworthiness for quantitative models means validity and reliability of provided information. However, this conception in qualitative studies is more unclear because it is determined by different terms. In qualitative research alike our proposed model, trustworthiness is relevant to address credibility, social responsibility, reputation and compatibility to low, that the findings of the research are credible, convenient, self-evident, and dependable. The total weight of the cluster is about $6 \%$ and the most important criteria are corporate social responsibility and reputation. Trustworthiness is considered by social responsibility and reputation criteria in sustainable supplier selection process in our proposed model as mentioned by Ada et al. (2021).

Table 7. Weights of sub-criteria within trustworthiness cluster.

\begin{tabular}{|c|c|}
\hline Sub-Criteria & Weights \\
\hline C5 $5_{1}$ - Credibility & 0.2292 \\
\hline $\mathrm{C} 5_{2}-$ Corporate Social Responsibility & 0.3250 \\
\hline $\mathrm{C} 5_{3}-$ Reputation & 0.2560 \\
\hline $\mathrm{C} 5_{4}-$ Compatibility to Law & 0.1898 \\
\hline
\end{tabular}

The weights of sub-criteria within technological ability cluster can be seen in Table 8 . Technological ability and technical skills, also known as infrastructure are the qualifications developed by company's knowhow, expertise, intelligence, technology and background. There are many different types of technical capabilities, but from managerial point of view, availability of information system, eco-friendly technologies, and sustainable production technologies are considered in our model. Technical skills vary mostly between industries and they are important because sustainable supplier selection must rely on technical abilities for agri-food supply chains to be more competitive. The total weight of technological ability cluster is $3 \%$, and the availability of information system is the most important criterion.

Table 8. Weights of sub-criteria within technological ability cluster.

\begin{tabular}{|c|c|}
\hline Sub-Criteria & Weights \\
\hline $\mathrm{C} 6_{1}-$ Information System & 0.5065 \\
\hline $\mathrm{C6}_{2}-$ Eco-friendly Technology & 0.2711 \\
\hline $\mathrm{C} 6_{3}-$ Level of Technology & 0.0931 \\
\hline $\mathrm{C6}_{4}-$ Sustainable Production Technologies & 0.1292 \\
\hline
\end{tabular}

The weights of main criteria, sub-criteria, and the overall weights can be seen in Table 9. The overall weights were calculated by multiplying the respective main criteria weights with each subcriteria weight. 
Table 9. Weights of criteria.

\begin{tabular}{|c|c|c|c|c|}
\hline Criteria & Criteria Weights & Sub-criteria & Sub-criteria Weights & Overall Weights \\
\hline \multirow[t]{7}{*}{ Economic } & 0.4407 & & & \\
\hline & & $\begin{array}{c}\mathrm{C} 1_{1}-\text { Cost of } \\
\text { Materials }\end{array}$ & 0.3853 & 0.1698 \\
\hline & & $\begin{array}{l}\mathrm{C1}_{2}-\text { Cost of } \\
\text { Transportation }\end{array}$ & 0.2495 & 0.1100 \\
\hline & & $\mathrm{C} 1_{3}$ - Discounts & 0.1120 & 0.0494 \\
\hline & & $\mathrm{C1}_{4}$ - Duty & 0.0753 & 0.0332 \\
\hline & & $\begin{array}{c}\mathrm{C}_{1}-\text { Cost of } \\
\text { Ordering }\end{array}$ & 0.0837 & 0.0369 \\
\hline & & $\begin{array}{c}\mathrm{C1}_{6}-\text { Price } \\
\text { Performance Ratio }\end{array}$ & 0.0941 & 0.0415 \\
\hline \multirow[t]{8}{*}{ Quality Issues } & 0.2446 & & & \\
\hline & & $\mathrm{C} 2_{1}-$ Assurance & 0.2255 & 0.0551 \\
\hline & & $\begin{array}{c}\mathrm{C} 2_{2}- \\
\text { Certifications } \\
\end{array}$ & 0.1261 & 0.0308 \\
\hline & & $\mathrm{C} 2_{3}-$ Reliability & 0.1595 & 0.0390 \\
\hline & & $\begin{array}{c}\mathrm{C} 2_{4}- \\
\text { Innovativeness }\end{array}$ & 0.2089 & 0.0511 \\
\hline & & $\mathrm{C} 2_{5}-\mathrm{R} \& \mathrm{D}$ & 0.0874 & 0.0214 \\
\hline & & $\begin{array}{c}\mathrm{C} 2_{6}- \\
\text { Improvement }\end{array}$ & 0.1164 & 0.0285 \\
\hline & & $\mathrm{C} 2_{7}-\mathrm{TQM}$ & 0.0763 & 0.0186 \\
\hline \multirow[t]{13}{*}{$\begin{array}{c}\text { Sustainable } \\
\text { Management } \\
\text { Systems } \\
\end{array}$} & 0.1699 & & & \\
\hline & & $\begin{array}{c}\mathrm{C} 3_{1} \text { - Sustainable } \\
\text { Design }\end{array}$ & 0.1180 & 0.0200 \\
\hline & & $\begin{array}{l}\mathrm{C} 3_{2}-\text { Energy- } \\
\text { Saving }\end{array}$ & 0.1688 & 0.0287 \\
\hline & & $\begin{array}{c}\mathrm{C} 3_{3}-\text { Reduction } \\
\text { of Pollution }\end{array}$ & 0.1242 & 0.0211 \\
\hline & & $\begin{array}{c}\mathrm{C} 3_{4} \text { - Sustainable } \\
\text { Manufacturing }\end{array}$ & 0.1708 & 0.0290 \\
\hline & & $\begin{array}{c}\mathrm{C} 3_{5} \text { - Reverse } \\
\text { Logistics }\end{array}$ & 0.1356 & 0.0230 \\
\hline & & $\begin{array}{l}\mathrm{C} 3_{6} \text { - Sustainable } \\
\text { Image }\end{array}$ & 0.0289 & 0.0049 \\
\hline & & $\begin{array}{c}\mathrm{C} 3_{7}-\text { Sustainable } \\
\text { Purchasing }\end{array}$ & 0.0419 & 0.0071 \\
\hline & & $\begin{array}{c}\mathrm{C} 3_{8} \text { - Sustainable } \\
\text { Logistics }\end{array}$ & 0.0611 & 0.0104 \\
\hline & & $\begin{array}{c}\mathrm{C} 3_{9} \text { - Sustainable } \\
\text { Packaging }\end{array}$ & 0.0437 & 0.0074 \\
\hline & & $\begin{array}{c}\mathrm{C} 3_{10}-\text { Waste } \\
\text { Control }\end{array}$ & 0.0465 & 0.0079 \\
\hline & & $\begin{array}{l}\mathrm{C} 3_{11} \text { - Using Eco- } \\
\text { friendly Materials }\end{array}$ & 0.0347 & 0.0059 \\
\hline & & $\begin{array}{c}\mathrm{C} 3_{12} \text { - Dedication } \\
\text { to Sustainable } \\
\text { Practices }\end{array}$ & 0.0258 & 0.0044 \\
\hline \multirow[t]{6}{*}{ Performance } & 0.0545 & & & \\
\hline & & $\begin{array}{c}\mathrm{C} 4_{1} \text { - Delivery on } \\
\text { Time }\end{array}$ & 0.0664 & 0.0036 \\
\hline & & $\begin{array}{l}\mathrm{C}_{2}-\text { Ability of } \\
\text { Communication }\end{array}$ & 0.0743 & 0.0040 \\
\hline & & $\mathrm{C} 4_{3}$ - Capacity & 0.0721 & 0.0039 \\
\hline & & $\mathrm{C} 4_{4}$ - Distance & 0.0584 & 0.0032 \\
\hline & & $\begin{array}{c}\mathrm{C} 4_{5}-\text { Fulfillment } \\
\text { Rate }\end{array}$ & 0.0652 & 0.0035 \\
\hline
\end{tabular}


Table 9 Continued...

\begin{tabular}{|c|c|c|c|c|}
\hline & & $\mathrm{C}_{4}$ - Lead Time & 0.0496 & 0.0027 \\
\hline & & $\mathrm{C}_{4}-$ Reactivity & 0.0483 & 0.0026 \\
\hline & & $\mathrm{C} 4_{8}-$ Warranty & 0.0351 & 0.0019 \\
\hline & & $\begin{array}{c}\mathrm{C} 4_{9}-\text { Consumer } \\
\text { Satisfaction }\end{array}$ & 0.1582 & 0.0086 \\
\hline & & $\begin{array}{c}\mathrm{C}_{10}-\text { After Sale } \\
\text { Management }\end{array}$ & 0.0392 & 0.0021 \\
\hline & & $\mathrm{C} 4_{11}$ - Resilience & 0.0371 & 0.0020 \\
\hline & & $\begin{array}{c}\mathrm{C}_{12}- \\
\text { Productiveness }\end{array}$ & 0.0745 & 0.0041 \\
\hline & & $\begin{array}{c}\mathrm{C} 4_{13}-\text { Technical } \\
\text { Caliber }\end{array}$ & 0.0259 & 0.0014 \\
\hline & & $\begin{array}{l}\mathrm{C} 4_{14}-\text { Shelf } \\
\text { Conditions }\end{array}$ & 0.0256 & 0.0014 \\
\hline & & $\begin{array}{c}\mathrm{C} 4_{15}-\text { Rate of } \\
\text { Rejections }\end{array}$ & 0.0250 & 0.0014 \\
\hline & & $\begin{array}{c}\mathrm{C} 4_{16}-\text { Frequency } \\
\text { of Orders }\end{array}$ & 0.0231 & 0.0013 \\
\hline & & $\begin{array}{l}\mathrm{C} 4_{17}-\text { Stock } \\
\text { Management }\end{array}$ & 0.0325 & 0.0018 \\
\hline & & $\mathrm{C}_{18}$ - Risk & 0.0262 & 0.0014 \\
\hline & & $\mathrm{C}_{19}-$ Security & 0.0222 & 0.0012 \\
\hline & & $\begin{array}{c}\mathrm{C} 4_{20}-\text { Strategic } \\
\text { Fitness }\end{array}$ & 0.0207 & 0.0011 \\
\hline & & $\mathrm{C}_{21}$ - Support & 0.0203 & 0.0011 \\
\hline \multirow[t]{5}{*}{ Trustworthiness } & 0.0564 & & & \\
\hline & & $\mathrm{C} 5_{1}$ - Credibility & 0.2292 & 0.0129 \\
\hline & & $\begin{array}{c}\mathrm{C} 5_{2}-\text { Corporate } \\
\text { Social } \\
\text { Responsibility } \\
\end{array}$ & 0.3250 & 0.0183 \\
\hline & & $\mathrm{C} 5_{3}-$ Reputation & 0.2560 & 0.0144 \\
\hline & & $\begin{array}{c}\mathrm{C} 5_{4}- \\
\text { Compatibility to } \\
\text { Law } \\
\end{array}$ & 0.1898 & 0.0107 \\
\hline \multirow[t]{5}{*}{$\begin{array}{c}\text { Technological } \\
\text { Ability }\end{array}$} & 0.0340 & & & \\
\hline & & $\begin{array}{c}\mathrm{C}_{1}-\text { Information } \\
\text { System }\end{array}$ & 0.5065 & 0.0172 \\
\hline & & $\begin{array}{c}\mathrm{C} 6_{2}-\text { Eco-friendly } \\
\text { Technology }\end{array}$ & 0.2711 & 00092 \\
\hline & & $\begin{array}{c}\mathrm{C}_{3}-\text { Level of } \\
\text { Technology }\end{array}$ & 0.0931 & 0.0032 \\
\hline & & $\begin{array}{c}\mathrm{C} 6_{4}-\text { Sustainable } \\
\text { Production } \\
\text { Technologies }\end{array}$ & 0.1292 & 0.0044 \\
\hline
\end{tabular}

Table 10. Ranking of alternatives.

\begin{tabular}{|c|c|}
\hline Suppliers & Qj Values \\
\hline Supplier E & 0 \\
\hline Supplier D & 0.2191 \\
\hline Supplier C & 0.2579 \\
\hline Supplier F & 0.4725 \\
\hline Supplier A & 0.5315 \\
\hline Supplier G & 0.8758 \\
\hline Supplier B & 0.9250 \\
\hline
\end{tabular}

Among others, economic criterion is the most important main criterion with a weight of 0.4407. Material cost and transportation cost were found as the most important sub-criteria with weights of 
0.1698 , and 0.11 , respectively. This result shows that, the most critical decisions for supplier selection process is economic decisions.

To provide a better understanding, the application was conducted in seven agri-food supplier companies. The company must improve supply chain performance while selecting the supplier at minimum cost, while also focusing on the social and environmental impacts. Table 10 shows the rankings of the alternatives with respect to criteria set.

Supplier E was found the most effective supplier considering 54 criteria.

\section{Discussion and Conclusion}

Selection of supplier is a vital process for the competitive performance of a supply chain. It is directly effective on enhanced business performance and in more general terms, reliable suppliers and good supplier relations expand responsiveness, honesty, and trust for all stakeholders. Nowadays, with increasing attention on sustainable supply chains, the requirement for decision support tools, based on multiple criteria models including all measurements of sustainability for agri-food supply chain development is obvious. In this research, a combined two-steps hybrid model in sustainable agri-food supply chain supplier selection process is developed.

This paper proposed a combined approach for the selection of suppliers within sustainable supply chain, utilizing multi criteria decision-making grounded on Fuzzy Analytic Network Process and fuzzy VIKOR methods. Integration of these methods facilitated addition of sustainability criteria to the supplier selection decision processes in agri-food supply chains.

According to the results among the seven suppliers, it is indicated that two of them (suppliers E and D) are highly reliable in terms of sustainable supplier selection process. It can be depicted that applicability of the proposed model to evaluate supplier performance is at acceptable levels. By analyzing expert opinions and evaluations of the managers for sustainable supplier selection through integrated methods and final outcomes have shown that how triple bottom line dimensions measured on a quantitative basis. The implications about managerial perspectives, especially for supplier relationship management, the basis for performance assessment must rely on the following criteria; material cost, transportation cost, quality assurance, innovation, energy saving, green manufacturing, communication skills, customer satisfaction, productivity, social responsibility, supplier reputation, information technology systems and environmentally friendly technology which were unveiled as the most determinant. The managers can further modify and adapt the model based on the specific constraints and priorities of various sectors. Therefore, the proposed model is highly flexible to be implemented in different sectors.

Business implications of the sustainable supplier selection model can be extended for integrated supply chain, by minimizing supply chain disturbances, and improvements on organizational structure. Such kind of improvements do not happen in short period of time, because linkages between suppliers and the firm can be transformed to good supplier relations with the contributions of a well-designed sustainable supplier selection process in the long run. First off all, upstream suppliers in the process of supplier relationship process, must be selected, certified and evaluated as major source of input with triple bottom line view.

Outcomes of the sustainable supplier selection criteria analysis in the first step of the model gives us valuable information about importance level and weights of them which can be used in the 
supplier selection process. As it is emphasized at the model development stage; economic, environmental, and social dimensions and their related major criteria with highest weights are summarized below in Table 11 .

Table 11. Summary.

\begin{tabular}{|lr|lr|lr|}
\hline \multicolumn{2}{|c|}{ Economic } & \multicolumn{2}{c|}{ Environmental } & \multicolumn{2}{c|}{ Social } \\
\hline Cost of material & $17 \%$ & Sustainable manufacturing & $3 \%$ & Consumer satisfaction & $1 \%$ \\
\hline Cost of transportation & $11 \%$ & Energy saving & $3 \%$ & Corporate social responsibility & $2 \%$ \\
\hline Productiveness & $0.5 \%$ & Eco-friendly technology & $1 \%$ & Reputation & $1.5 \%$ \\
\hline Innovativeness & $5 \%$ & & Assurance & $6 \%$ \\
\hline Information System & $2 \%$ & & & $10.5 \%$ \\
\hline
\end{tabular}

According to the evaluations of supply chain managers of agri-food firms in Turkish market, economic dimension of triple bottom line is the most important one, other performance dimensions, social is the second important and environmental is the third important for the supplier selection decision. For the supply chain manager of an emerging economy, economic criteria and factors are still most important in decision making but there are some optimistic evidences about the environmental and social criteria would be considered in the near future.

Availability of quality assurance system with $6 \%$ weight is a devoted criterion in the supplier selection process for supplier certification and evaluation. Innovativeness is another remarkable criterion which is important for developing collaborative design platform with suppliers. Availability of information system is another criterion for information exchange and benchmarking between suppliers and supply chain. Environmental criteria with relative weights, sustainable manufacturing, energy saving and eco-friendly technology are important for the establishment of green procurement infrastructure.

Based on the developed model and conclusions, managers, decision-makers, and practitioners should benefit the proposed framework and proposed model structure can be used as a base to generate a decision support system. The business companies and supply chains can use the model as an effective tool to manage sustainable supplier selection process. Future possible research may focus on finding the relationships between the criteria and using different MCDM techniques to determine the appropriate suppliers. This study conducts an implementation in Turkey, within an emerging economy context, which can be indicated as a limitation of this study.

\section{Conflict of Interest}

The authors confirm that there is no conflict of interest to declare for this publication.

\section{Acknowledgments}

This research did not receive any specific grant from funding agencies in the public, commercial, or not-for-profit sectors. The authors would like to thank the editor and anonymous reviewers for their comments that help improve the quality of this work. 


\section{References}

Ada, E., Sagnak, M., Kazancoglu, Y., Luthra, S., Kumar, A. (2021). A Framework for evaluating information transparency in supply chains. Journal of Global Information Management, 29(6), 1-22.

Ahumada, O., \& Villalobos, J.R. (2009). Application of planning models in the agri-food supply chain: A review. European Journal of Operational Research, 196(1), 1-20.

Alkahtani, M., Khalid, Q.S., Jalees, M., Omair, M., Hussain, G., \& Pruncu, C.I. (2021). E-Agricultural supply chain management coupled with blockchain effect and cooperative strategies. Sustainability, 13(2), 129. https://doi.org/10.3390/su13020816.

Badraoui, I., van der Lans, I., Boulaksil, Y., \& van der Vorst, J.G. (2021). Antecedents of horizontal logistics collaboration in agri-food supply chains. The International Journal of Logistics Management, (Accepted). https://doi.org/10.1108/IJLM-09-2020-0362.

Banaeian, N., Mobli, H., Fahimnia, B., Nielsen, I.E., \& Omid, M. (2018). Green supplier selection using fuzzy group decision making methods: A case study from the agri-food industry. Computers \& Operations Research, 89, 337-347.

Barbosa, M.W. (2021). Uncovering research streams on agri-food supply chain management: A bibliometric study. Global Food Security, 28, 100517.

Beiki, H., Seyedhosseini, S.M, Ponkratov, V.V., Zekiy, A.O., \& Ivanov, S.A. (2021). Addressing a sustainable supplier selection and order allocation problem by an integrated approach: a case of automobile manufacturing. Journal of Industrial and Production Engineering, 38(4), 239-253.

Ciccullo, F., Cagliano, R., Bartezzaghi, G., \& Perego, A. (2021). Implementing the circular economy paradigm in the agri-food supply chain: The role of food waste prevention technologies. Resources, Conservation and Recycling, 164, 105114.

Costa, C., Antonucci, F., Pallottino, F., Aguzzi, J., Sarriá, D., \& Menesatti, P. (2013). A review on agri-food supply chain traceability by means of RFID technology. Food and Bioprocess Technology, 6(2), 353366.

De, A., \& Singh, S.P. (2021). A resilient pricing and service quality level decision for fresh agri-product supply chain in post-COVID-19 era. The International Journal of Logistics Management, (Accepted). https://doi.org/10.1108/IJLM-02-2021-0117.

Du, Y., Zhang, D., \& Zou, Y. (2020). Sustainable supplier evaluation and selection of fresh agricultural products based on IFAHP-TODIM model. Mathematical Problems in Engineering, 2020, 1-15.

Gkountani, V.A., Tsoulfas, G.T., \& Rachaniotis, N.P. (2021, November). Circular economy and resilience: convergences and deviations in the case of agri-food supply chains. In 2021 IOP Conference Series: Earth and Environmental Science, 2nd International Conference on Environmental Design (Vol. 899, No. 1, pp. 012001). IOP Publishing. Athens, Greece.

Gogou, E., Katsaros, G., Derens, E., Alvarez, G., \& Taoukis, P.S. (2015). Cold chain database development and application as a tool for the cold chain management and food quality evaluation. International Journal of Refrigeration, 52, 109-121.

Hong, W., Cai, Y., Yu, Z., \& Yu, X. (2018). An agri-product traceability system based on iot and blockchain technology. In 2018 1st IEEE International Conference on Hot Information-Centric Networking (pp. 254-255). IEEE. Shenzhen, China.

Kaur, H., \& Singh, S.P. (2021). Multi-stage hybrid model for supplier selection and order allocation considering disruption risks and disruptive technologies. International Journal of Production Economics, 231,107830 . 
Khan, A.U., \& Ali, Y. (2021). Sustainable supplier selection for the cold supply chain (CSC) in the context of a developing country. Environment, Development and Sustainability, 23(9), 13135-13164.

Liu, Y., Eckert, C., Yannou-Le Bris, G., \& Petit, G. (2019). A fuzzy decision tool to evaluate the sustainable performance of suppliers in an agrifood value chain. Computers \& Industrial Engineering, 127, 196-212.

Lu, J., Zhang, S., Wu, J., \& Wei, Y. (2021). COPRAS method for multiple attribute group decision making under picture fuzzy environment and their application to green supplier selection. Technological and Economic Development of Economy, 27(2), 369-385.

Mabrouk, N.B. (2021). Green supplier selection using fuzzy Delphi method for developing sustainable supply chain. Decision Science Letters, 10(1), 63-70.

Mahmoudi, A., Deng, X., Javed, S.A., \& Zhang, N. (2021). Sustainable supplier selection in megaprojects: Grey ordinal priority approach. Business Strategy and the Environment, 30(1), 318-339.

Meena, S.R., Meena, S.D., Pratap, S., Patidar, R., \& Daultani, Y. (2019). Strategic analysis of the Indian agrifood supply chain. Opsearch, 56(3), 965-982.

Mishra, R., Singh, R.K., \& Subramanian, N. (2021). Impact of disruptions in agri-food supply chain due to COVID-19 pandemic: contextualised resilience framework to achieve operational excellence. The International Journal of Logistics Management (Accepted). https://doi.org/10.1108/JJLM-01-20210043.

Orji, I.J., \& Ojadi, F. (2021). Investigating the COVID-19 pandemic's impact on sustainable supplier selection in the Nigerian manufacturing sector. Computers \& Industrial Engineering, 160, 107588.

Puška, A., Nedeljković, M., Zolfani, S.H., \& Pamučar, D. (2021). Application of interval fuzzy logic in selecting a sustainable supplier on the example of agricultural production. Symmetry, 13(5), 1-20.

Rana, R.L., Tricase, C., \& De Cesare, L. (2021). Blockchain technology for a sustainable agri-food supply chain. British Food Journal, 123(11), 3471-3485.

Reklitis, P., Sakas, D.P., Trivellas, P., \& Tsoulfas, G.T. (2021). Performance implications of aligning supply chain practices with competitive advantage: empirical evidence from the agri-food sector. Sustainability, 13(16), 1-21.

Sagnak, M. (2019). Selecting the most appropriate supplier in the green environment: a hybrid multi-criteria decision-making application. In: García-Alcaraz, J.L., Jamil, G.L., Avelar-Sosa, L., Peñalver, A.J.B. (eds) Handbook of Research on Industrial Applications for Improved Supply Chain Performance. IGI Global, Hershey, pp. 101-124.

Santoso, I., Purnomo, M., Sulianto, A.A., \& Choirun, A. (2021, November). Machine learning application for sustainable agri-food supply chain performance: a review. In 2021 IOP Conference Series: Earth and Environmental Science, International Conference on Green Agro-industry and Bioeconomy (Vol. 924, No. 1, pp. 012059). IOP Publishing. Malang, Indonesia.

Saurabh, S., \& Dey, K. (2021). Blockchain technology adoption, architecture, and sustainable agri-food supply chains. Journal of Cleaner Production, 284, 124731.

Sharma, M.K., Dhaka, V.S., \& Shekhawat, R.S. (2021). Intelligent agro-food chain supply. In: Pattnaik, P.K., Kumar, R., Pal, S. (eds) Internet of Things and Analytics for Agriculture. Springer, Singapore, (Vol. 3, pp. 65-91).

Shaw K., Shankara, R., Yadava, S.S, \& Thakurb, L.S. (2012). Supplier selection using fuzzy AHP and fuzzy multi-objective linear programming for developing low carbon supply chain. Expert Systems with Applications, 39(9), 8182-8192. 
Shi, H., Quan, M.Y., Liu, H.C., \& Duan, C.Y. (2018). A novel integrated approach for green supplier selection with interval-valued intuitionistic uncertain linguistic information: A case study in the agrifood industry. Sustainability, 10(3), 1-18.

Tavana, M., Yazdani, M., \& Di Caprio, D. (2017). An application of an integrated ANP-QFD framework for sustainable supplier selection. International Journal of Logistics Research and Applications, 20(3), 254275.

UNEP, I. (2010). Assessing the environmental impacts of consumption and production-priority products and materials. A Report of the Working Group on the Environmental Impacts of Products and Materials to the International Panel for Sustainable Resource Management. Hertw.

Verdecho, M.J., Alarcón-Valero, F., Pérez-Perales, D., Alfaro-Saiz, J.J., \& Rodríguez-Rodríguez, R. (2021). A methodology to select suppliers to increase sustainability within supply chains. Central European Journal of Operations Research, 29(4), 1231-1251.

Xie, G. (2015). Modeling decision processes of a green supply chain with regulation on energy saving level. Computers \& Operations Research, 54, 266-273.

Yan, B., Fan, J., Cai, C., \& Fang, J. (2020). Supply chain coordination of fresh Agri-products based on value loss. Operations Management Research, 13(3), 185-196.

Yazdani, M., Pamucar, D., Chatterjee, P., \& Torkayesh, A.E. (2021a). A multi-tier sustainable food supplier selection model under uncertainty. Operations Management Research, (Accepted). https://doi.org/10.1007/s12063-021-00186-z.

Yazdani, M., Torkayesh, A.E., Stević, Ž., Chatterjee, P., Ahari, S.A., \& Hernandez, V.D. (2021b). An interval valued neutrosophic decision-making structure for sustainable supplier selection. Expert Systems with Applications, 183, 115354.

Yu, Y., \& Xiao, T. (2017). Pricing and cold-chain service level decisions in a fresh agri-products supply chain with logistics outsourcing. Computers \& Industrial Engineering, 111, 56-66.

Yu, Y., Xiao, T., \& Feng, Z. (2020). Price and cold-chain service decisions versus integration in a fresh agriproduct supply chain with competing retailers. Annals of Operations Research, 287(1), 465-493.

Zhang, J., Yang, D., Li, Q., Lev, B., \& Ma, Y. (2021). Research on sustainable supplier selection based on the rough DEMATEL and FVIKOR methods. Sustainability, 13(1), 1-20. 